Article

\title{
Analysis of the Changing Landscape of a World Heritage Site: Case of Luang Prabang, Lao PDR
}

\author{
Ceelia Leong ${ }^{1, *}$, Jun-ichi Takada ${ }^{2}$ and Shinobu Yamaguchi ${ }^{3}$ \\ 1 Department of International Development Engineering, Graduate School of Science and Engineering, \\ Tokyo Institute of Technology, Tokyo 152-8550, Japan \\ 2 School of Environment and Society, Tokyo Institute of Technology, Tokyo 152-8550, Japan; \\ takada@ide.titech.ac.jp \\ 3 Global Scientific and Computing Center, Tokyo Institute of Technology, Tokyo 152-8550, Japan; \\ yamaguchi@gsic.titech.ac.jp \\ * Correspondence: ceelia@ap.ide.titech.ac.jp; Tel.: +81-3-5734-3282
}

Academic Editor: Victor T. King

Received: 28 June 2016; Accepted: 29 July 2016; Published: 4 August 2016

\begin{abstract}
The Luang Prabang World Heritage Site experienced tremendous change caused by rapid development and tourism growth. It is recognized that change is inevitable in evolving historic urban cities. Adequate information is essential in formulating strategies to manage change without compromising heritage values. Existing studies are critical of the impact of tourism negatively transforming Luang Prabang but lack in-depth analysis and a significant sample size to clearly discern the changes. This paper addresses the need to visualize the significant changes affecting the built environment of the core inscribed area of Luang Prabang World Heritage. Geographic information systems (GIS) were applied to compare the landscape between 1999 and 2009 based on indicators adopted from the Safeguarding and Preservation Plan (PSMV). Four significant changes were identified as follows: (1) there was an evident shift from residential to touristic use, particularly to guesthouses; (2) Lao traditional architecture has replaced modern architecture; (3) modern building materials have replaced traditional building materials; and (4) traditional roof materials have replaced modern roof materials. Changes in landscape were interpreted and factors that caused the changes were identified from the local stakeholders' perspective.
\end{abstract}

Keywords: World Heritage Site; change; built environment; GIS; Luang Prabang

\section{Introduction and Objective}

The inscription of a World Heritage title comes with positive and negative implications [1,2]. The inscription has brought many benefits in terms of social development, economic development, and international recognition. Tourism plays an important role in generating employment and reducing poverty in a World Heritage Site. However, cultural heritage sites in less developed countries in Asia are facing an acute situation from having the fastest tourism growth rate in the world [3]. Moreover, the tourism is still in its developing stages, and it is difficult to sustain heritage tourism. Tourism demands without proper planning can trigger uncontrolled development and degrade the state of the heritage site [2]. Development needs often contradict conservation needs [4]. Lessons learned from the devastating effects of unplanned development and overly strict conservation have shown that a historic city needs both continuity and change [5,6]. Historic cities need to thrive and develop socio-economically [7]. As such, change is inevitable. Rather than halting change, flexibility to cope with and react to change is vital for sustainability of the city. Therefore, it is imperative that the dynamics of change in heritage cities be understood and change managed without undermining the outstanding universal value (OUV) [4]. 
The heritage conservation approach has evolved from isolated individual monuments to include the surrounding landscape [6,8]. This greatly expanded the scale and scope of conservation. The paradigm shift in the heritage conservation approach has introduced use of mapping tools, especially geographical information systems (GIS), for the purpose of urban preservation and historic morphology $[9,10]$. The use of GIS is resourceful, as it facilitates digitizing historical maps and comparing the changes over time. GIS serves as a common platform to converge urban planners, heritage managers, and policy makers and thereby facilitate decision making in drawing sound development and management plans for heritage sites.

This study looks into the case of Luang Prabang, Lao PDR, which is facing similar challenges from intense development pressure. The urban landscape is undergoing tremendous change in a relatively short period of time. An urgent warning was issued that the site is on the verge of becoming a world heritage in danger [11]. One of the recommendations given by the World Heritage Committee (WHC) was to prepare an updated map to show the full extent of the changes that occurred. The maps are expected to provide information that is critical to drawing urgent urban planning strategies that rectify negative changes. In the guideline for monitoring World Heritage Sites, the baseline used to measure change needs to reflect the original state of the World Heritage Site [12]. Therefore, it is important to use indicators related to authenticity and integrity that convey the OUV, as the baseline.

Given this background, the objective of this study is to identify the state of preservation of the landscape of Luang Prabang and clarify the extent to which the site has changed since its inscription as a heritage site. This study aims to visualize significant changes in the built environment of Luang Prabang by using GIS. GIS is applied while taking into consideration the local constraints and conditions. Thematic mappings of Luang Prabang in 1999 and 2009 are compared and analyzed based on the seven indicators identified in the Safeguarding and Preservation Plan (Plan de Sauvegard et de Mise en Valeur (PSMV)) $[13,14]$. The analysis is also supported by interpretation of the changes and investigation of the factors that led to these changes from the local perspective.

\section{The Study Site}

\subsection{Luang Prabang World Heritage Site}

Luang Prabang is the ancient capital city of the former Kingdom of Lan Xang, established some 1200 years ago [15]. Figure 1 shows that Luang Prabang is located in the north region of Lao PDR between the confluence of the Mekong River and the Nam Khan River. The heritage site is situated in a clay basin and enclosed by limestone mountains. It became a World Heritage Site in 1995 based on the three criteria (ii), (iv), and (v):

(ii) to exhibit an important interchange of human values, over a span of time or within a cultural area of the world, on developments in architecture or technology, monumental arts, town-planning, or landscape design;

(iv) to be an outstanding example of a type of building, architectural or technological ensemble or landscape which illustrates (a) significant stage(s) in human history; and

(v) to be an outstanding example of a traditional human settlement, land-use, or sea-use which is representative of a culture (or cultures), or human interaction with the environment especially when it has become vulnerable under the impact of irreversible change [16] (p. 47). 


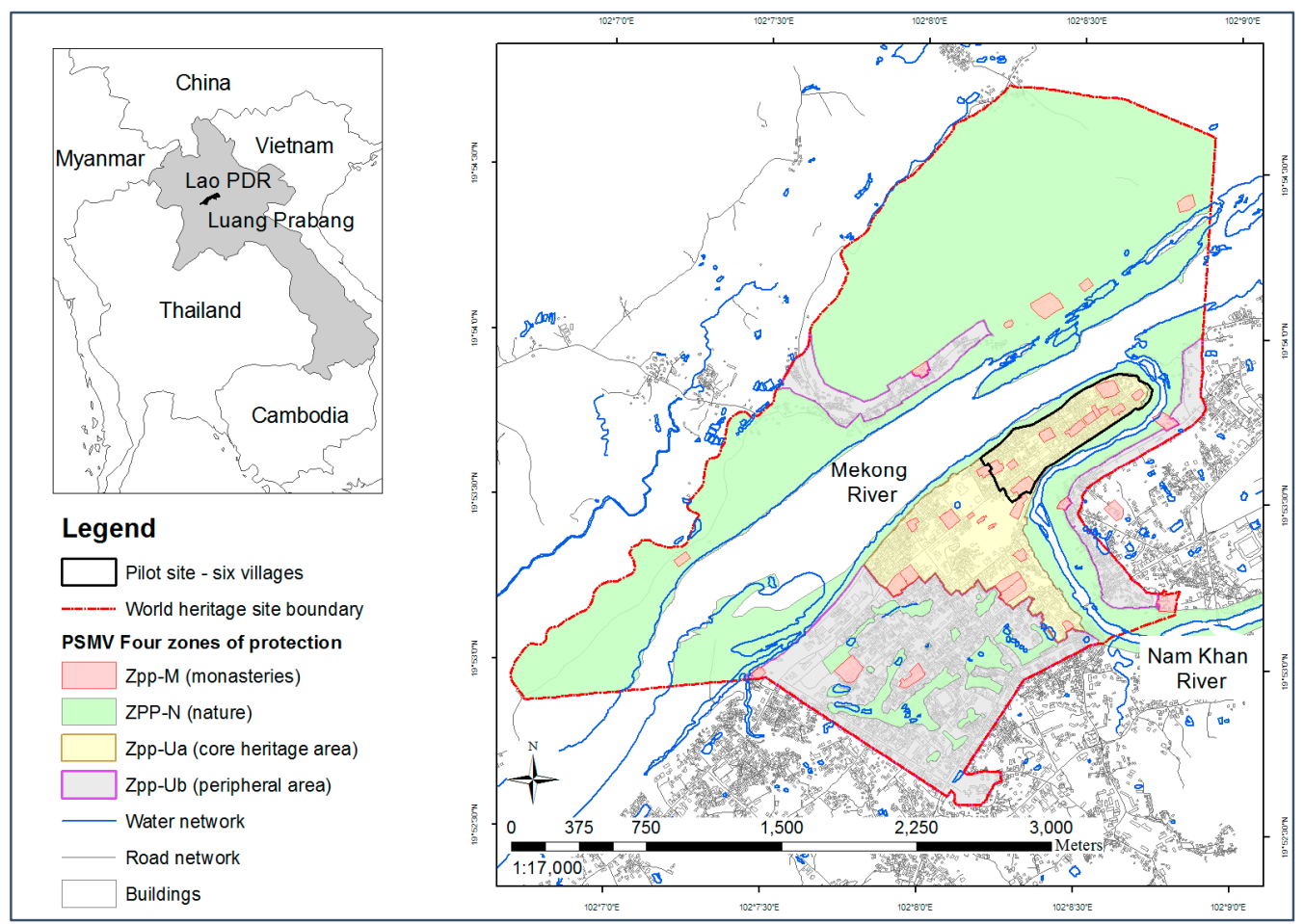

Figure 1. Luang Prabang World Heritage Site.

The inscribed area of 708.53 ha encompasses 29 villages, 611 inventory buildings, and 183 protected wetlands [11]. Inventory buildings are significant heritage listed buildings. The buildings are classified into "inventory PSMV" and "inventory UNESCO" [14]. The site is well known for its unique overlay of Lao-French urban landscape, mixture of diverse architecture, and coexistence between the built and natural environments. In the early Lao settlement, monasteries built parallel to the rivers were surrounded by clusters of villages [17]. Traditional Lao morphology was greatly influenced by the natural environment and the social role of Buddhism. Then, the French colonials and urbanization introduced town planning that formed a grid pattern of roads and blocks. This new urban form has been assimilated harmoniously with the existing traditional Lao settlement.

The Lao traditional architecture comprised vernacular houses on stilts constructed of bamboo and timber [18]. The upper floor was the living quarters and the lower floor was an open area for various uses, such as protection against flood. With the influence of the French, the Lao traditional architecture evolved to incorporate masonry materials (e.g., limewash brick-and-mortar) and European construction techniques. When the local lifestyle changed, the lower floor was enclosed with masonry to convert it into living quarters. Later, modernization introduced techniques and materials such as concrete. In its Advisory Body Evaluation, the International Council on Monuments and Sites (ICOMOS) evaluated Luang Prabang's authenticity and stated that "the level of authenticity of materials and techniques of many of the domestic buildings in Luang Prabang is low since modern techniques and materials (especially concrete) have been used to replace traditional materials over a long period. The quality of the temples and monasteries is higher. However, the overall landscape and urban fabric of the town are still authentic to a high degree" [15] (p. 4).

The population of the World Heritage Site did not change much since its inscription in $1995(20,380)$ [19] until $2011(19,068)$ [20]. However, the site experienced an unprecedented increase of foreign and local tourists. The number soared by $875 \%$ from 62,348 in 1997 to 607,584 in 2015 [21]. Touristic accommodations, such as hotels and guesthouses, surged dramatically by $1290 \%$ from 29 in 1997 to 403 in 2015 [21]. 


\subsection{Conservation Framework}

The Luang Prabang preservation framework was jointly developed by Chinon City, France and the Lao government under the aegis of the United Nations Educational, Scientific and Cultural Organization (UNESCO) [13]. The management mechanism and regulatory plan were developed to ensure the development and protection of the site. The Heritage House (La Maison du Patriomoine $(\mathrm{MdP}))$ was established to manage and monitor development in the heritage area according to the PSMV, to provide consultation to locals, to approve building permits, and to manage conservation and infrastructure projects. Since 2001, the PSMV has been implemented as a regulatory tool for four different zones of protection: Zpp-Ua (core heritage area with a high concentration of historical monuments), Zpp-Ub (peripheral area), Zpp-M (monasteries), and Zpp-N (nature) [14]. Figure 1 illustrates the four different protection zones in the heritage site. In 2009, MdP's mandate was upgraded to the provincial department level as the Department of the Luang Prabang World Heritage (La Department du Patrimoine Luang Prabang (DPL)).

\section{Literature Review}

Luang Prabang has changed rapidly due to an unprecedented increase in tourists and touristic accommodations. Existing literature has attempted to analyze the changes affecting the heritage site and have presented mixed findings. Three major reports have shown growing concern that the sharp tourism growth has negatively transformed Luang Prabang's landscape. The reports are namely: the UNESCO tourism impact report [22], the Japan Bank International Corporation (JBIC) evaluation of tourism development report [23], and the reactive monitoring report from the World Heritage Committee [11]. Five negative impacts highlighted are as follows: (1) rapid construction using inappropriate styles, techniques, and materials [11,22]; (2) over-densification of buildings [11]; (3) excessive concentration of tourists and tourism businesses [11,23]; (4) loss of Lao traditional houses in favor of modern houses [11]; and (5) migration of local residents to outside the heritage site [11]. They also noted that the locals tend to use modern building materials [11,22] and roof materials [22] for varying reasons, such as low durability, cost, vulnerability to climate, influence of media, and others. Effective implementation of preservation regulations could overcome the challenges of preservation and revive traditional materials [22]. On the other hand, the Asian Development Bank (ADB) report [24] on good practices of urbanization in Asia has credited Luang Prabang for its good coordination between urban development and preservation. Strict physical intervention has helped to preserve the site. The DPL has implemented the strictest building regulations ever observed in the country.

Sitthivan [25], Dearborn and Stallmeyer [26,27], and Vonvilay [28] have attempted different methods to assess change in the built environment of Luang Prabang. Sitthivan tried to evaluate the implementation of the PSMV and identify problems in conservation by analyzing authorized and unauthorized constructions from 2002 until 2003 [25]. He found that the locals violated regulations regarding building size, roof shape, and building materials because they lacked knowledge of said regulations and constructed the buildings by themselves without the help of experts [25]. Dearborn and Stallmeyer [26,27] made their observations by walking around in villages of the core heritage area. They examined a sample of 19 buildings and compared them with the PSMV. Their study supported the observations made by the reactive monitoring mission report [11]. They further claimed that the PSMV has valorized particular heritage and that the local authorities have removed heritage elements that were inconvenient to political interests and the heritage title.

On the other hand, Vonvilay [28] has revealed different findings indicating that the Lao houses have maintained their aesthetic because of regulations. He analyzed the transformation of five cases of Lao traditional architecture by comparing the original and transformed floor plans in terms of spatial formation, components, and elements. The locals have changed the interior use of space and integrated the old traditional building with modern construction techniques based on their current lifestyle and local conditions. Although globalization and economic factors do influence the transformation of Lao houses, preservation regulations were able to make Lao houses transform in a way that still preserves the heritage values. 
Moreover, Staiff and Bushell [29] questioned the analysis and conclusions derived by Dearborn and Stallmeyer [26,27] and the authors of the WHC mission report, Boccardi and Logan [11]. They pointed out the lack of analysis used to understand the dynamic relationship between tourism and heritage. The two studies oversimplified the complexity of the problems faced, and the observations made were Western critiques towards the modernity and change in Luang Prabang. Staiff and Bushell [29] tried to use mobility theory, which treats modernity as a fluid state rather than static. Interestingly, they felt that the change in Luang Prabang should not be feared but treated as a process that could be negotiated.

In summary, a majority of the literature is critical of the impacts of development and tourism growth in Luang Prabang. However, some have revealed different findings and perceptions. The previous studies on built environment lacked in-depth analysis and a sample size significant enough to provide a holistic view and clearly discern the changes occurring in Luang Prabang. Since the change in the built environment of Luang Prabang remained unclear, it was difficult to define the limits of acceptable change. Poor understanding of change makes it difficult to formulate effective strategies to manage change. Moreover, the full implication of changes in Luang Prabang requires a comparison with the original state of the landscape documented at the time of inscription [12]. So far, GIS has only been applied to the wetlands $[30,31]$ and not to the built environment of Luang Prabang.

\section{Methodology}

The application of GIS had long been demanded by the DPL for heritage management. However, the sustainable use of GIS in the local environment was identified as an issue. Therefore, it is crucial to deploy GIS in a sustainable manner by addressing local constraints and adapting its use to the local environment. Comparative case studies of GIS application in World Heritage Sites and urban cities in Asia and on-site assessment of GIS use in Luang Prabang were carried out as preparation to guide the application [32]. There are four components of GIS application: (1) data collection; (2) development of an appropriate geospatial database; (3) development of a reliable base map; and (4) spatial analysis of the landscape. A pilot site of six villages in the core heritage area, Zpp-Ua, was identified based on significant representation of inventory buildings (206 out of 611 , or $34 \%$ ). Figure 1 also displays the location of the pilot site in the core heritage area, which is enclosed by a black line.

\subsection{Data Collection}

It is important to identify the essential data required for spatial analysis. During the development of the PSMV, indicators that were prone to change over time were identified [13] (Table 1). In 1999, the DPL and the Chinon Development and City Planning Agency (ADUC) collected the indicators for the urban morphology study, architectural study, and land survey. They were documented in the PSMV maps. It was considered the closest to the original state since the inscription of the heritage site. In order to update the indicators, authors and the Construction and Restoration Unit of the DPL conducted an extensive field survey of each building in the pilot site. Indicators were verified by local architects during the survey. All indicators and terminologies used in this study follow the definitions in the PSMV.

Table 1. Description of seven indicators according to the Safeguarding and Preservation Plan (Plan de Sauvegard et de Mise en Valeur (PSMV)) [13,14].

\begin{tabular}{ll}
\hline \multicolumn{1}{c}{ Indicator } & \multicolumn{1}{c}{ Description } \\
\hline Building usage & Building function utilized for public and private purposes \\
\hline Building architecture & $\begin{array}{l}\text { Building typology derived from Lao vernacular architecture and the } \\
\text { architecture of foreign influences }\end{array}$ \\
\hline Building materials & Materials used to construct building structure \\
\hline Building roof materials & Materials used to construct roof structure \\
\hline Building height & Estimation of height based on number of floors of inhabitable structures \\
\hline Building condition & State of building evaluated based on its structural condition \\
\hline Building area size & Floor area of a building \\
\hline
\end{tabular}




\subsection{Development of an Appropriate Geospatial Database}

Building attributes are stored and managed in the free and open source software (FOSS) database management system PostgreSQL on Linux. PostgreSQL is a database server, and any clients on other machines can access the data. PostgreSQL was used to create a heritage database in the past to manage information on heritage buildings and wetlands [33]. The user interface was redesigned, and the database was expanded to include the updated building attributes. Commercial software ArcGIS version 9.3.1 (ESRI, Redlands, CA, United States) was selected for the spatial analysis because it was widely used and made available by other conservation projects in the DPL. Although PostgreSQL and ArcGIS run on different platforms, they are connected through a network by installing the plug-in Object Linking and Embedding Database (OLE DB) in ArcGIS. Data were converted using another FOSS PostGIS that can handle compatible data formats with ArcGIS. PostGIS provides support for geographic objects to the PostgreSQL database by specifying the type of geometry, dimension, and geographic projection.

\subsection{Development of a Reliable Base Map}

A base map functions as a spatial reference to identify objects in the surrounding terrain and supports advanced cartography and analysis. Hence, it is vital to identify good mapping sources if one is to develop a reliable base map for buildings. The existing base maps available at the national and local levels cannot be directly used because of inaccurate building shape, size, and location. Therefore, six mapping resources were identified [34]: (1) scanned topographic maps; (2) a CAD drawn map for the PSMV; (3) Lao national base map; (4) Google Earth image; (5) high resolution satellite image; and (6) building polygons delineated from high resolution satellite images. The maps were re-projected or georeferenced to find the accurate building position, alignment, and polygon shapes.

\subsection{Spatial Analysis}

Thematic mappings in 1999 and 2009 were analyzed based on visual comparison [35] and tracking transition in change [36]. The constraint of spatial data and small study area faced by this study is similar to Stewart's case study in Cairo, Egypt [35]. This study adopted Stewart's approach in using visual comparison to conduct discrete analysis of a rapidly changing urban landscape at the parcel level. Detail change can be examined building by building, which is crucial for heritage preservation. Each indicator has a range of different categories. It is important to track the transition from the original category to different categories [36]. The locations of changed and unchanged areas are mapped for easier visualization and to avoid overcrowding of diverse changes.

Significant changes were interpreted through a workshop with local experts of the DPL. The results of the spatial analysis were presented before the DPL and discussed. Seven local experts from the Construction and Restoration Unit, Urban Planning Unit, and Environmental Unit participated.

\subsection{Investigation with Local Residents}

The workshop with local experts of the DPL helped to identify major changes that were worthwhile to investigate further with local residents. The investigation aimed to find the reason behind change in the built environment from the local residents' perspective. The use of GIS is instrumental in identifying buildings that have changed significantly. The whole cohort, which refers to all local residents living in the changed buildings, was interviewed. The list of plausible factors were derived from literature [22] and identified through workshop. Face to face interviews were conducted based on the list of factors, which was derived using a close-ended questionnaire. The interview was translated into the Lao language and conducted with the help of the Construction and Restoration Unit of the DPL. 


\section{Results and Discussion}

This section summarizes and discusses the most significant changes identified in four indicators, namely: building usage, architecture, building materials, and roof materials. A total of 789 buildings in the pilot site were analyzed. The analysis is supported by an interpretation of the changes by local experts of the DPL and an investigation of the factors that led to change with local residents. Figure 2 shows the spatial distribution of inventory buildings in the pilot site, which will be referred to in the spatial analysis of each indicator.

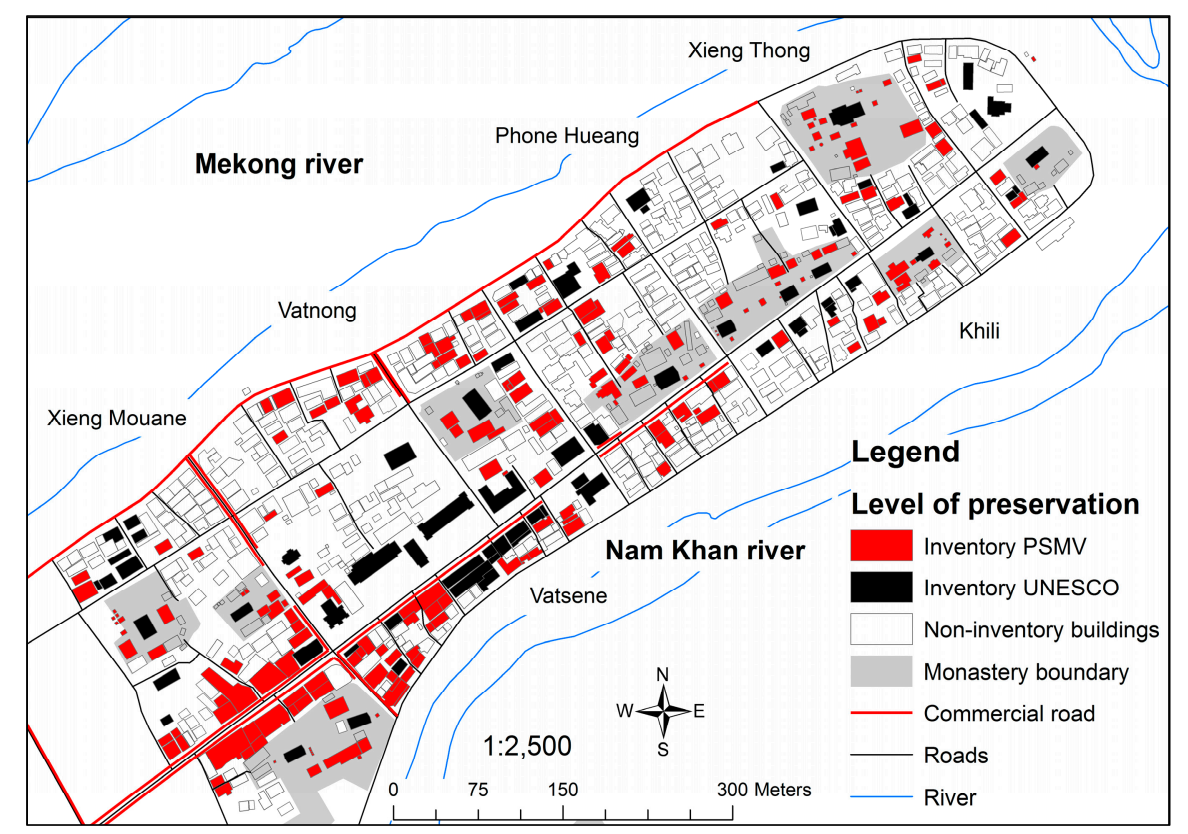

Figure 2. Spatial distribution of inventory buildings in pilot site.

\subsection{Change in Building Usage}

Building usage in Luang Prabang can be grouped into four categories: (1) residential; (2) touristic; (3) religious; and (4) miscellaneous usages. Miscellaneous usages include government, commerce, and a mix of residential and small business. Figure $3 a-c$ show the spatial distribution of building usage in 1999 and 2009 as well as the change in usage. In the interval of 10 years, there was a substantial increase in touristic buildings due to the conversion of residential buildings and the construction of new touristic buildings. Growth of touristic buildings is prevalent along main roads and river banks. This indicates that these areas are lucrative tourism locations. Religious buildings and government buildings remained sparsely distributed and maintained open space in the middle of the peninsula. 


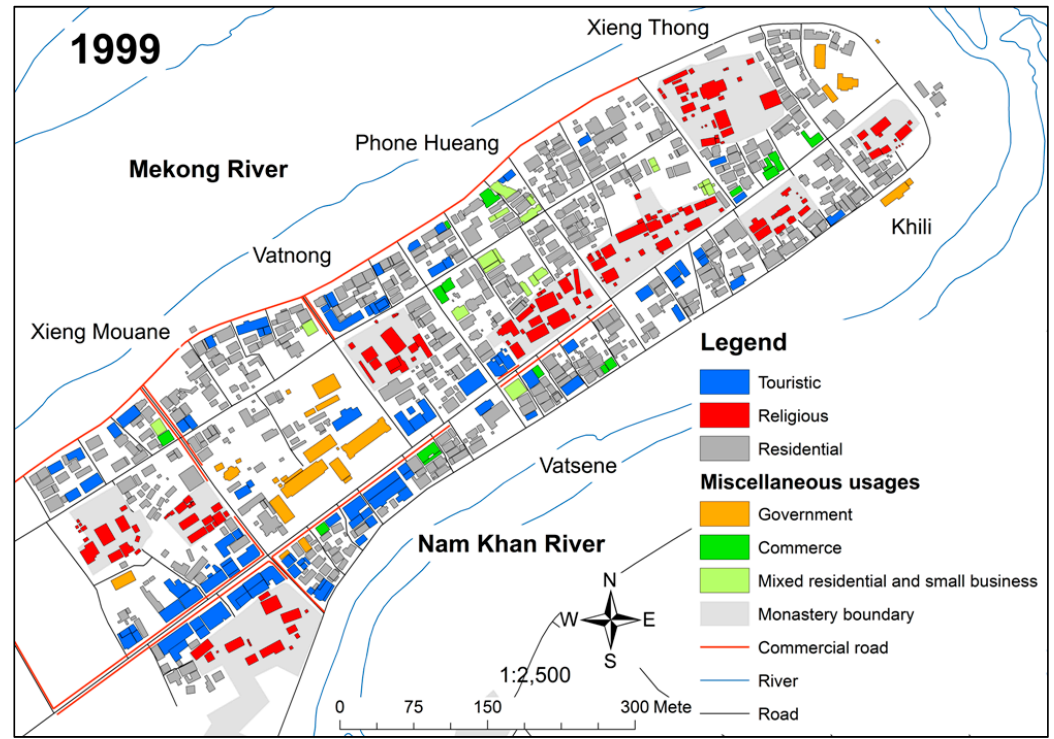

(a)

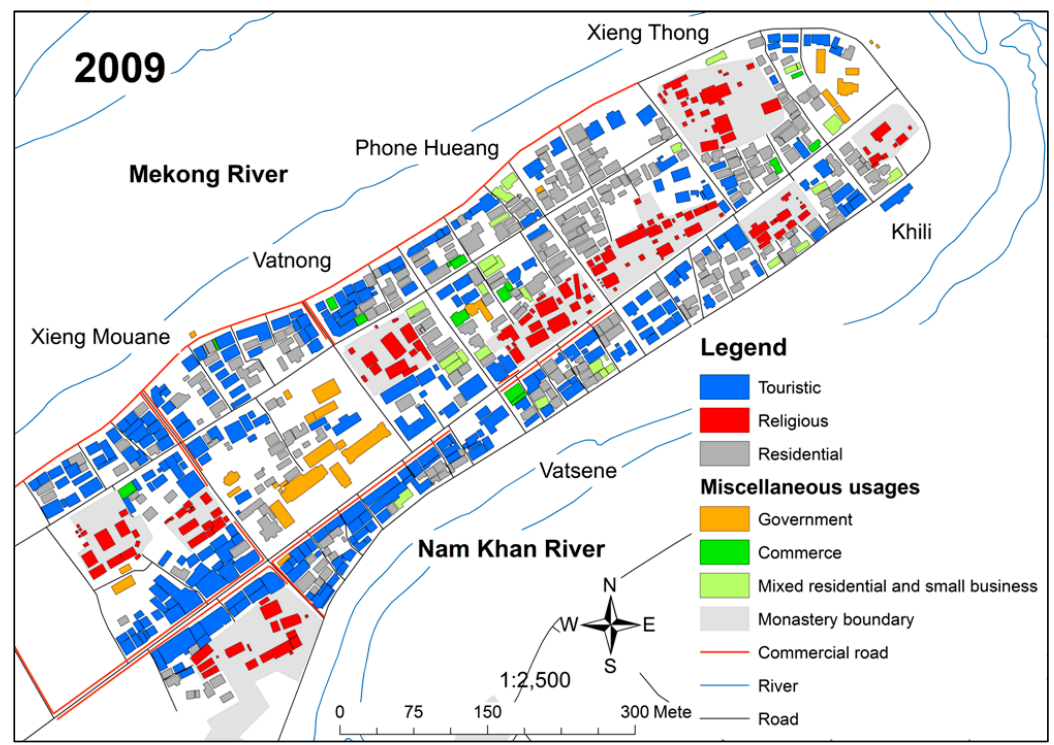

(b)

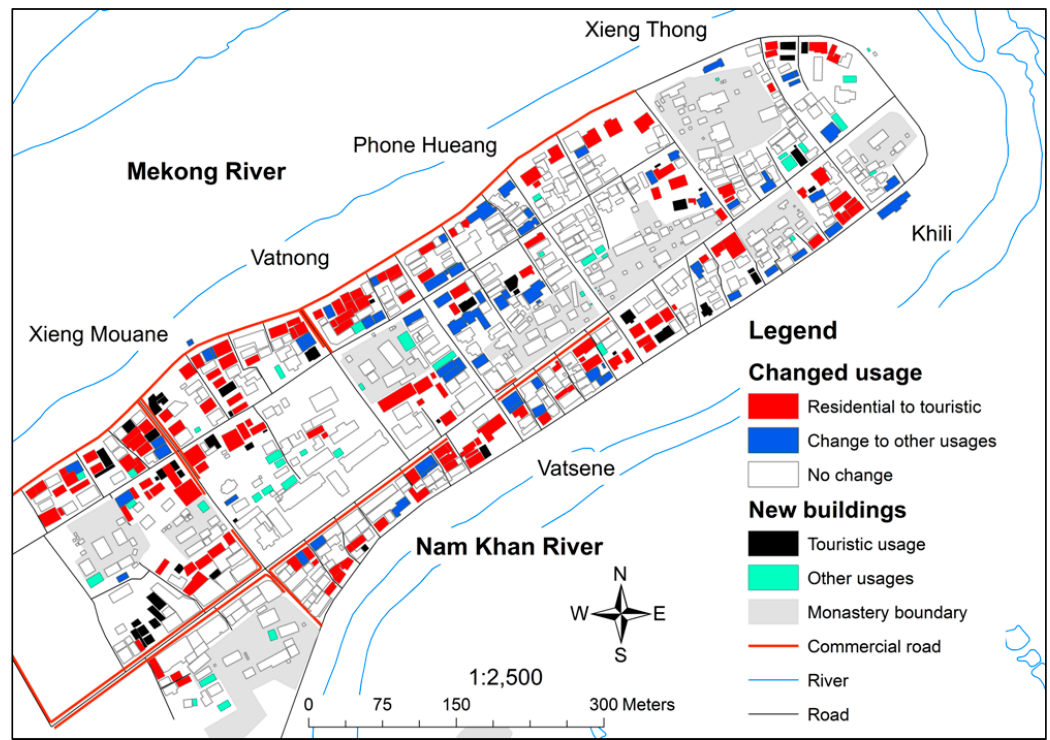

(c)

Figure 3. (a) Spatial distribution of building usage in 1999; (b) spatial distribution of building usage in 2009; and (c) change in building usage between 1999 and 2009. 
Table 2 shows the transition in building usage between 1999 and 2009. There were 428 residential buildings in 1999. By 2009, only 231 remained as residential, and 141, about a third of the residential buildings, converted to touristic usage. Conversion to miscellaneous usages only accounts for 23 cases and demolished buildings for 33 cases. This resulted in a decrease of the total number of residential buildings to 268 in 2009. Meanwhile, total touristic buildings increased notably from 66 in 1999 to 252 in 2009. Among new buildings, touristic usage is highest in number (45), followed by residential (22), religious (15), and miscellaneous usages (6). It is important to note that religious buildings from 1999 did not change much (150 out of 160) and that only 10 were demolished. Miscellaneous usage buildings are relatively small in number and did not change significantly.

Table 2. Transition in building usage between 1999 and 2009.

\begin{tabular}{|c|c|c|c|c|c|c|c|}
\hline & & \multicolumn{5}{|c|}{2009} & \multirow[b]{2}{*}{ Total } \\
\hline & & Residential & Touristic & Religious & Miscellaneous Usages & None $^{1}$ & \\
\hline \multirow{6}{*}{1999} & Residential & 231 & 141 & 0 & 23 & 33 & 428 \\
\hline & Touristic & 10 & 53 & 0 & 3 & 0 & 66 \\
\hline & Religious & 0 & 0 & 150 & 0 & 10 & 160 \\
\hline & Miscellaneous usages & 5 & 13 & 0 & 28 & 1 & 47 \\
\hline & None ${ }^{1}$ & 22 & 45 & 15 & 6 & 0 & 88 \\
\hline & Total & 268 & 252 & 165 & 60 & 44 & 789 \\
\hline
\end{tabular}

1 "None" in 1999 refers to new buildings and in 2009 refers to demolished buildings.

It was revealed during a workshop with the DPL that the religious and government buildings did not change much due to varying reasons. Government buildings, such as government offices and public schools, faced a lack of funds and limited public land available at the heritage site. Religious buildings lacked funds and restoration experience. Only the well-known monasteries gathered restoration funds from entrance fees; however, other monasteries relied on donations from the local community. Although there were art schools to transfer skills from masters to apprentices, apprentices still lacked enough experience to properly restore the temples. Only a handful of craftsmen possessed excellent skills and adequate experience.

Touristic usage consists of guesthouses, hotels, restaurants, and touristic commerce (e.g., spas, boutiques, tour agencies, internet cafes, and others). Guesthouses have increased most prominently. Table 3 shows the four types of touristic usage that increased from converted residential and new buildings. Among the 141 buildings converted from residential to touristic, 78 converted to guesthouses, which is highest in number. Similarly, among the 45 newly built touristic buildings, 24, more than half, were guesthouses.

Table 3. Four types of touristic usage that increased from converted residential and new buildings.

\begin{tabular}{ccc}
\hline Type of Touristic Usage & Converted from Residential & New Buildings \\
\hline Guesthouse & 78 & 24 \\
Touristic commerce & 27 & 6 \\
Restaurant & 22 & 8 \\
Hotel & 14 & 7 \\
Total & 141 & 45 \\
\hline
\end{tabular}

It is evident that privately owned buildings, such as residential houses, have been converted to guesthouses to cope with the sharp influx of tourists and the growing demand. Conversion to a guesthouse is easier for locals to do when starting a touristic business if they have little capital and can only offer a small number of rooms [37]. Hotels increased less due to the criteria imposed by the Lao National Tourism Administration (LNTA). A hotel requires at least 15 rooms, $70 \%$ of which need to be larger than $10 \mathrm{~m}^{2}$, and must provide services compliant to international standards. 


\subsection{Change in Building Architecture}

There are five groups of architecture classified as follows: (1) Lao traditional architecture; (2) commercial architecture (Chinese-Vietnamese shop houses); (3) French colonial architecture; (4) religious architecture; and (5) modern architecture. Figure 4a-c illustrate the spatial distribution of building architecture in 1999 and 2009 as well as the change in architecture. The most significant change detected is the increase of Lao traditional architecture due to conversion from modern architecture and the construction of new Lao traditional architecture buildings. This trend is more prevalent along river bank areas than it is in the middle of the peninsula. Commercial architecture remained concentrated along commercial roads on the Nam Khan river side. Colonial architecture and religious architecture continued to occupy the middle of the peninsula. These buildings did not change architecture because the majority are inventory buildings.

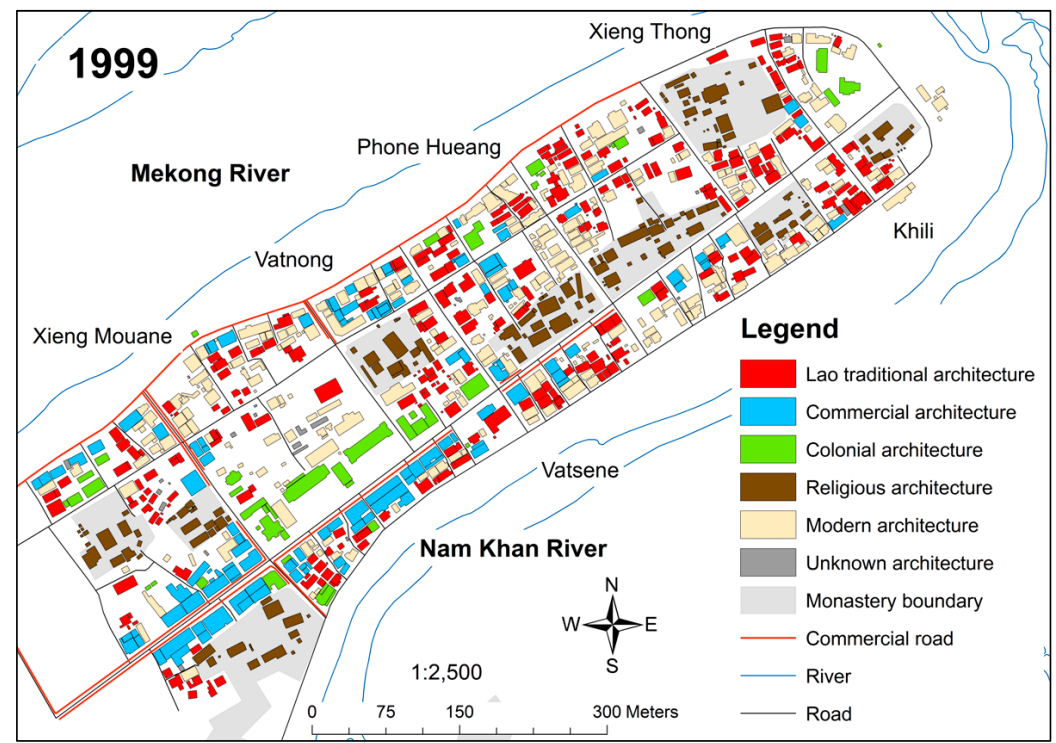

(a)

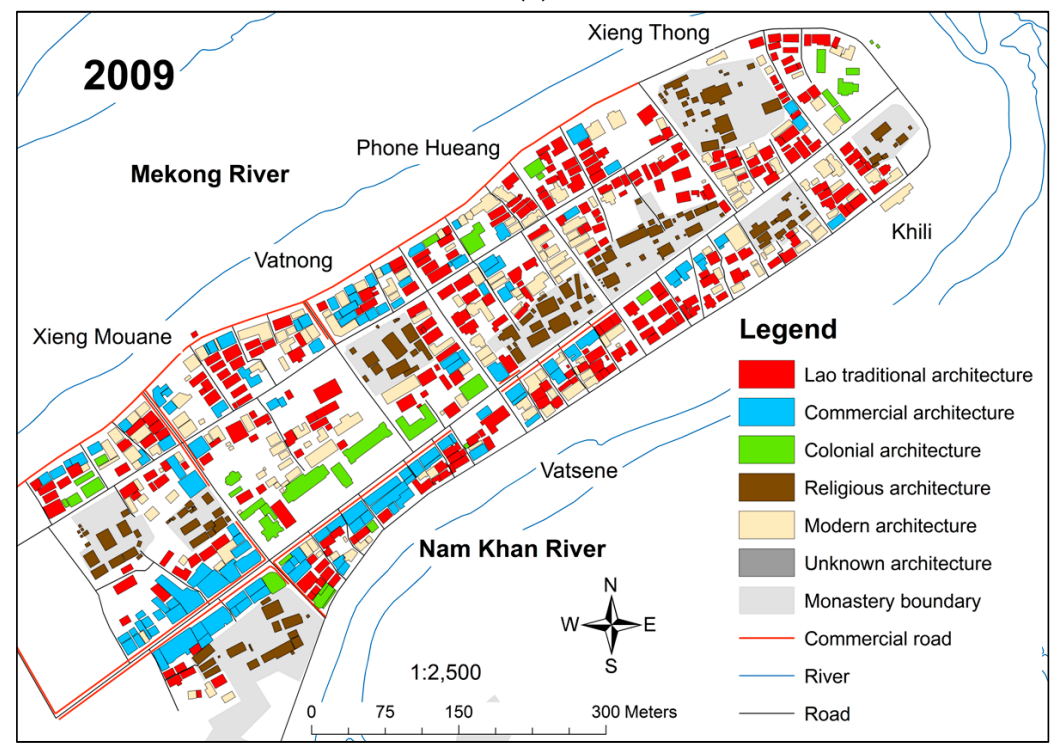

(b)

Figure 4. Cont. 


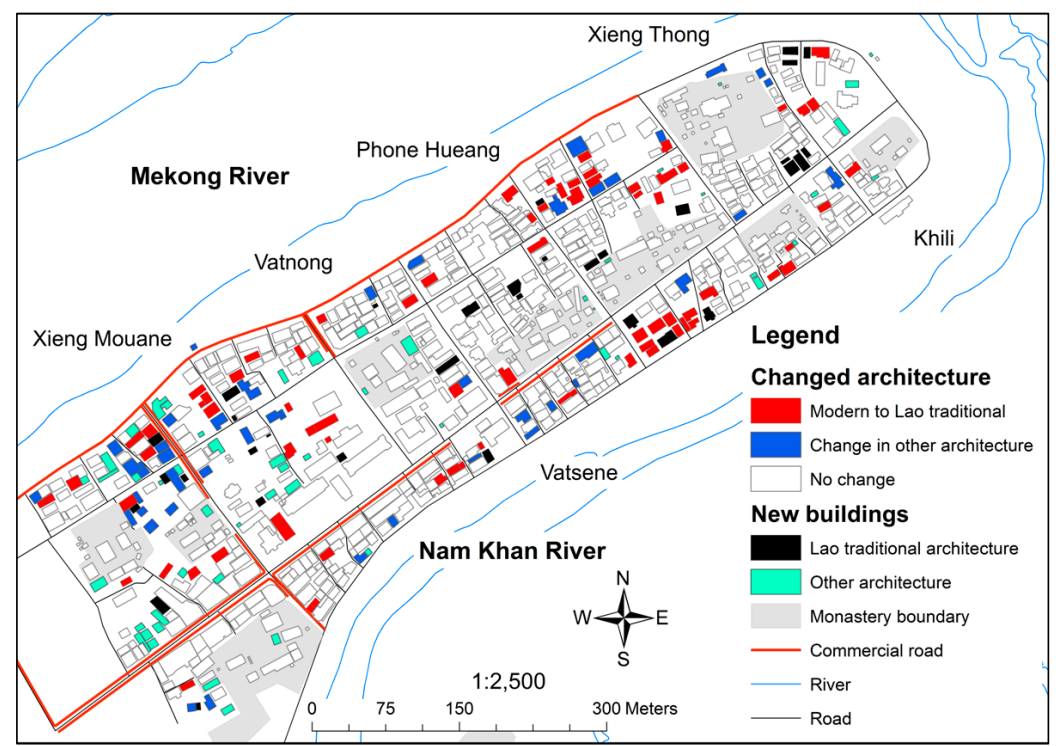

(c)

Figure 4. (a) Spatial distribution of building architecture in 1999; (b) spatial distribution of building architecture in 2009; and (c) change in building architecture between 1999 and 2009.

Table 4 summarizes the transition of building architecture between 1999 and 2009. Modern architecture buildings in 1999 account for 219 buildings, and 73 of them were converted to Lao traditional architecture. Among the 88 buildings newly built between 1999 and 2009, 33 were of Lao traditional architecture. Moreover, 157 Lao traditional architecture buildings were retained out of 197. Owing to these trends, Lao traditional architecture buildings increased from 197 to 278 within 10 years. In contrast, modern architecture buildings decreased from 219 to 180 . The three other types of architecture, i.e. commercial, colonial, and religious, did not change significantly. Therefore, it can be deduced that buildings of modern influence have been reverted to Lao traditional architecture.

Table 4. Transition in building architecture between 1999 and 2009.

\begin{tabular}{|c|c|c|c|c|c|c|c|c|}
\hline & & \multicolumn{6}{|c|}{2009} & \multirow[b]{2}{*}{ Total } \\
\hline & & Modern & Lao Traditional & Commercial & Colonial & Religious & None & \\
\hline \multirow{8}{*}{1999} & Modern & 123 & 73 & 10 & 0 & 0 & 13 & 219 \\
\hline & Lao traditional & 22 & 157 & 5 & 0 & 0 & 13 & 197 \\
\hline & Commercial & 1 & 4 & 69 & 0 & 0 & 0 & 74 \\
\hline & Colonial & 0 & 1 & 0 & 27 & 0 & 4 & 32 \\
\hline & Religious & 0 & 0 & 0 & 0 & 150 & 10 & 160 \\
\hline & Unknown $^{1}$ & 4 & 10 & 1 & 0 & 0 & 4 & 19 \\
\hline & None & 30 & 33 & 7 & 3 & 15 & 0 & 88 \\
\hline & Total & 180 & 278 & 92 & 30 & 165 & 44 & 789 \\
\hline
\end{tabular}

${ }^{1}$ Unknown are buildings that were mistakenly left out in the map of 1999 due to human error.

Local experts interpreted that the increase of Lao traditional architecture had a positive impact on the landscape because it reinforced the traditional elements of the urban landscape. The Lao traditional architecture complemented the landscape harmoniously with existing buildings in a few aspects [13,14]. The roof ridges of Lao traditional architecture buildings were aligned parallel to the rivers. Lao traditional architecture buildings are regulated to occupy up to $40 \%$ of the total land area, and the rest should be covered by green plantations. The limited percentage of land occupancy of traditional architecture maintained spaces between buildings. These characteristics are important for preserving the Lao urban morphology. The increase of Lao traditional architecture buildings is attributed to strict implementation of the PSMV. Section 1, Article 3 of the PSMV stipulated that only two typologies of architecture are permitted for rebuilt and new buildings: Lao traditional and 
commercial architecture [14]. However, most of the houses were built as Lao traditional architecture because commercial architecture is restricted to commercial roads only.

This finding concurs with Vonvilay [28] but differs from Boccardi and Logan [11], who claimed that Lao traditional architecture buildings have reduced in number. The report attributed the decrease of Lao traditional architecture buildings to preference for modern architecture and the conversion of residential buildings to touristic accommodations. First of all, Lao traditional architecture buildings have increased and they did not decreased. Regarding these two reasons, the first has already been disproven as more buildings changed from modern architecture to Lao traditional architecture, not vice versa. To examine the second reason, buildings that changed from residential to touristic are classified by the types of transition of architecture in Table 5 . Among 131 buildings, only five buildings changed from Lao traditional architecture to modern architecture. Therefore, the second reason cannot be justified, either.

On the contrary, it is revealed in Table 5 that 40 buildings changed usage from residential to touristic but still maintained same Lao traditional architecture. Discussion with the DPL disclosed that it would be worthwhile to investigate further the motivation of residents because tourism demand is positively benefitting the maintenance of Lao traditional architecture.

Table 5. Classification of the buildings that changed from residential to touristic use.

\begin{tabular}{cc}
\hline & Residential Converted to Touristic \\
\hline Changed architecture & \\
\hline Modern to Lao traditional & 27 \\
Lao traditional to modern & 5 \\
Other changes in architecture & 8 \\
\hline Maintained same architecture & \\
\hline Lao traditional & 40 \\
Modern & 26 \\
Commercial & 19 \\
Colonial & 6 \\
Religious & 0 \\
Total & 131 \\
\hline
\end{tabular}

Investigation with Local Residents

A total of 40 local residents who maintained Lao traditional architecture despite changing from residential to touristic use were interviewed using a multiple-choice questionnaire. Seventy-five responses were collected. The list of plausible motivations used in the questionnaire was identified prior during a workshop with the DPL. Local residents rated six motivations, as shown in Figure 5. The two major reasons given were to "follow regulations" $(21,52.5 \%)$ and to "preserve heritage values" $(17,42.5 \%)$. Local experts pointed out that three reasons are interrelated, namely "follow regulations", "preserve heritage values", and "attractive for business." Locals need to abide by the PSMV to obtain certificate for completion of construction. It is compulsory to have a certificate for completion of construction in order to apply for a touristic business license from the Department of Tourism. Through the application procedures and interaction with the DPL and Department of Tourism, local residents recognized the importance of heritage values. Furthermore, the residents perceived Lao traditional architecture as a good prospect for business since it was considered attractive to the foreign tourists who want to experience Lao culture and heritage. Hence, respecting the regulations is the prerequisite to obtaining a touristic business license. 


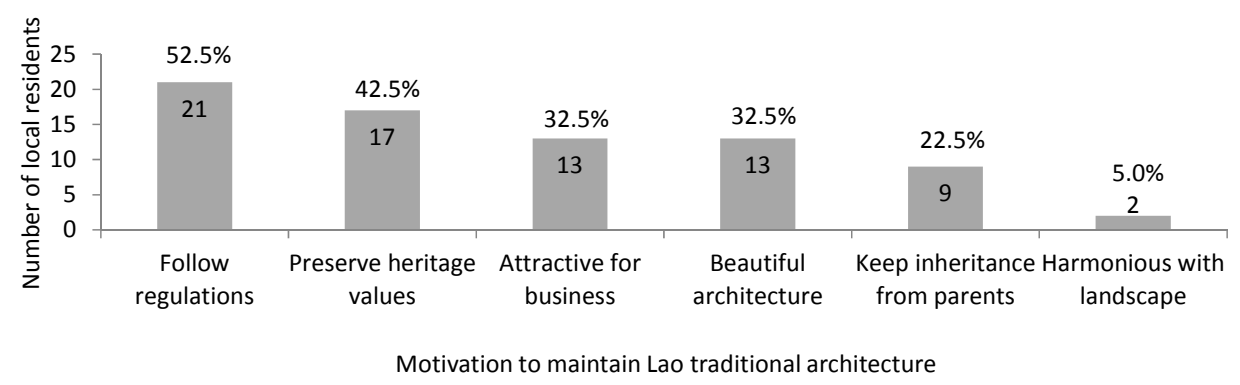

Figure 5. Locals' motivation for maintaining Lao traditional architecture despite changing from residential to touristic use ( $n=40$ respondents, 75 responses).

\subsection{Change in Building Materials}

Both traditional and modern buildings are used in Luang Prabang. Traditional materials are made of a combination of locally available raw materials, i.e., timber, bamboo, brick-and-mortar, and plaster. Modern materials incorporate the use of foreign materials such as cement or a combination of cement and timber. Figure 6a-c illustrate the spatial distribution of building materials in 1999 and 2009 as well as the significant change in materials. The most significant change is that modern materials have replaced traditional materials. The change to modern materials occurred throughout the peninsula. It is observed that inventory buildings located in the middle of the peninsula and on commercial roads along the Nam Khan riverside have continued to use traditional materials. This corresponds with the unchanged architecture in Section 5.2.

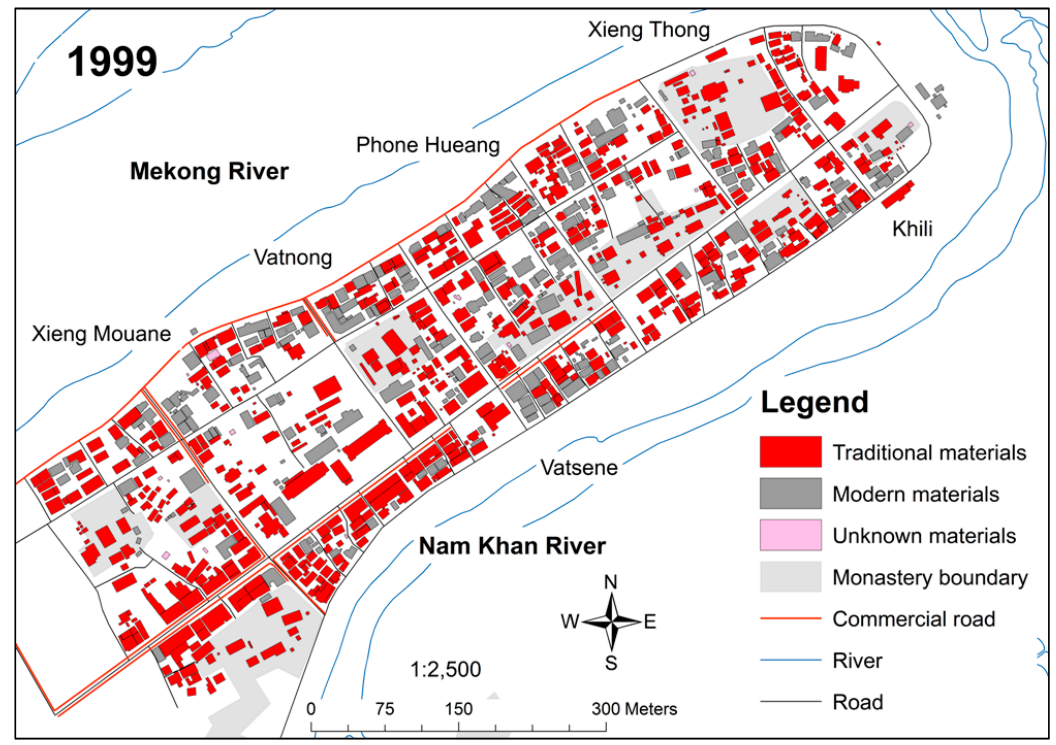

(a)

Figure 6. Cont. 


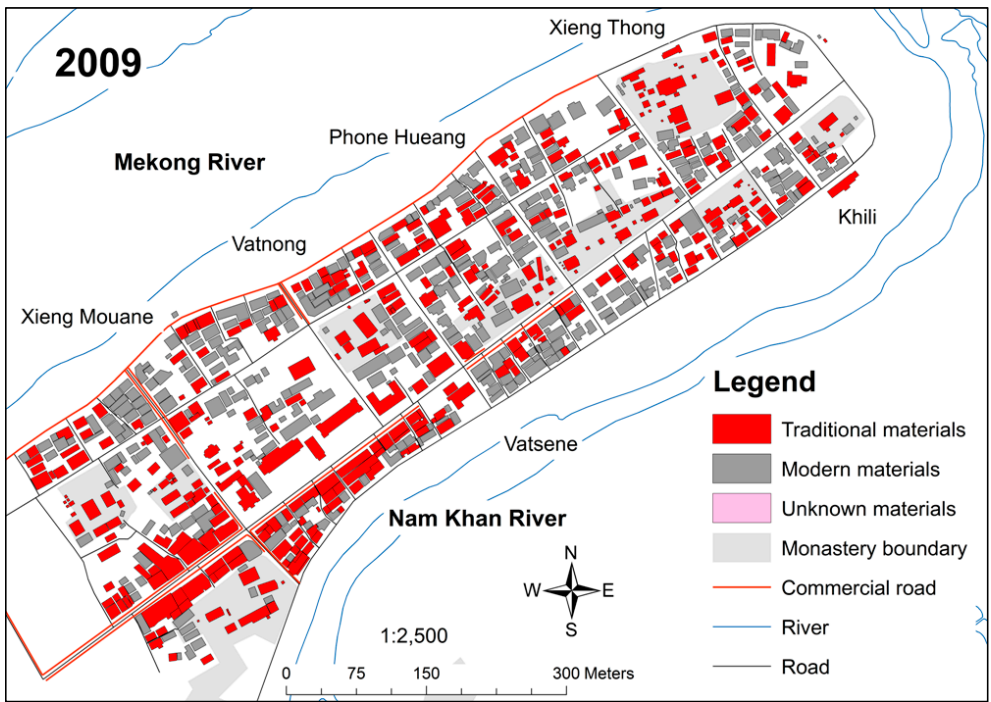

(b)

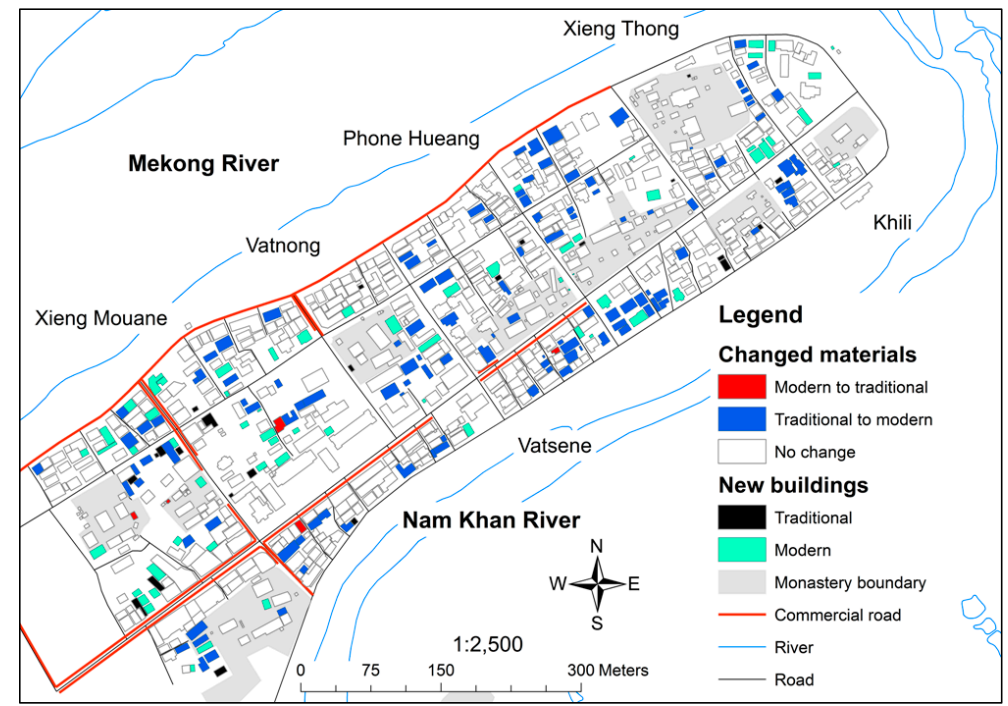

(c)

Figure 6. (a) Spatial distribution of building materials in 1999; (b) spatial distribution of building materials in 2009; and (c) change in building materials between 1999 and 2009.

Table 6 shows the transition in building materials between 1999 and 2009. A decade later, buildings using traditional materials had reduced from 487 to 376, while buildings using modern materials increased from 201 to 369 . Three major changes were identified: (1) buildings using traditional materials were converted to those using modern materials; (2) buildings using traditional materials were demolished; and (3) new buildings were constructed using modern materials.

Table 6. Transition in building materials between 1999 and 2009.

\begin{tabular}{cccccc}
\hline & & \multicolumn{4}{c}{$\mathbf{2 0 0 9}$} \\
\cline { 3 - 6 } & & Modern & Traditional & None & Total \\
\hline \multirow{3}{*}{1999} & Modern & 187 & 5 & 9 & 201 \\
& Traditional & 112 & 341 & 34 & 487 \\
& Unknown & 9 & 3 & 1 & 13 \\
& None & 62 & 26 & 0 & 88 \\
& Total & 369 & 376 & 44 & 789 \\
\hline
\end{tabular}

${ }^{1}$ Same description as Table 4. 
Local experts regarded the increase of modern materials to have minimal impact on the landscape because the materials were coated and not visible. They considered paint color, type of architecture, building size, and roof to have higher impact on the overall landscape than coated materials. Section 1, Article 11.3 of the PSMV allows the use of concrete, stone, or steel as long as they are not apparent and are coated [14]. Article 11.4 dictates that the colors of the external coat should be chosen from the palette of traditional colors. The use of traditional materials is only mandatory for inventory buildings. Although use of traditional building materials has decreased, they viewed the maintenance of traditional materials in inventory buildings as sufficient to represent the preservation of traditional materials.

The change in building materials concurs with the UNESCO tourism impact report [22], Boccardi and Logan [11], and Vonvilay [28]. However, Boccardi and Logan viewed the change to modern materials as not compliant with the regulations. From the local experts' point of view, the change to modern materials was not against the regulations.

\section{Investigation with Local Residents}

Local residents who converted to modern materials could be driven by diverse reasons. Table 7 lists the potential factors that may affect the choice of materials. There are 12 factors. Of which, factor number 1-9 were retrieved from the report of UNESCO [22] and factor number 10-12 were identified by local experts of the DPL. All 112 residents who changed to modern materials were interviewed using questionnaires with a four-point Likert scale. Positive responses are grouped to derive percentages. The percentages of responses are classified into three categories, as shown in Table 8. A similar classification applies to ratings of traditional and modern materials.

Table 7. Potential factors that influence locals in their selection of building materials [22].

\begin{tabular}{|c|c|c|c|}
\hline Number & Factor & Type & Description \\
\hline 1 & Durability & Inherent characteristic & Lifespan of materials \\
\hline 2 & Cooling effect & Inherent characteristic & Ability to ventilate air within building \\
\hline 4 & Affordability & External factor & Ability to purchase materials \\
\hline 6 & Construction technique & External factor & $\begin{array}{l}\text { Choice of construction technique based on time consumed } \\
\text { and level of technical difficulty }\end{array}$ \\
\hline 7 & Flexibility of regulations & External factor & $\begin{array}{l}\text { Flexibility of the PSMV regulations on types of building } \\
\text { materials that can be used }\end{array}$ \\
\hline 8 & Availability of labor & External factor & Presence of skilled craftsmanship \\
\hline 11 & Ability to filter noise & Inherent characteristic & $\begin{array}{l}\text { Ability to filter noise pollution, e.g., human activities and } \\
\text { traffic congestion }\end{array}$ \\
\hline 12 & $\begin{array}{l}\text { Government } \\
\text { logging policies } 1\end{array}$ & External factor & $\begin{array}{l}\text { Only applicable to traditional materials. Use of timber that is } \\
\text { not affected by government policies that control the annual } \\
\text { logging quota for export and domestic use. }\end{array}$ \\
\hline
\end{tabular}


Table 8. Classification of the percentages of positive responses.

\begin{tabular}{cccc}
\hline $\begin{array}{c}\text { Percentage of } \\
\text { Positive Responses }\end{array}$ & $\begin{array}{c}\text { Important in Influencing } \\
\text { the Use of Materials }\end{array}$ & Inherent Characteristic & External Factor \\
\hline Less than $50 \%$ & Not influential & Weak & Not good \\
Between $50 \%$ and $75 \%$ & Influential & Strong \\
More than $75 \%$ & Very influential & Very strong & Very good \\
\hline
\end{tabular}

As shown in Figure 7, local residents have rated each of the potential factors that could influence their selection of materials. Five factors were classified as highly influential: (1) flexibility of regulations; (2) ability to withstand wet climate and insects; (3) durability of materials; (4) availability of materials; and (5) availability of labor. Six other factors were also considered to be influential. However, "symbol of modernity, status, and wealth" was not influential, indicating that the aesthetic of the building materials was not significant. This differs from the UNESCO tourism impact report [22] that televised images of modern buildings and lifestyle in Thailand gave locals the impression that modern materials are better and prestigious.

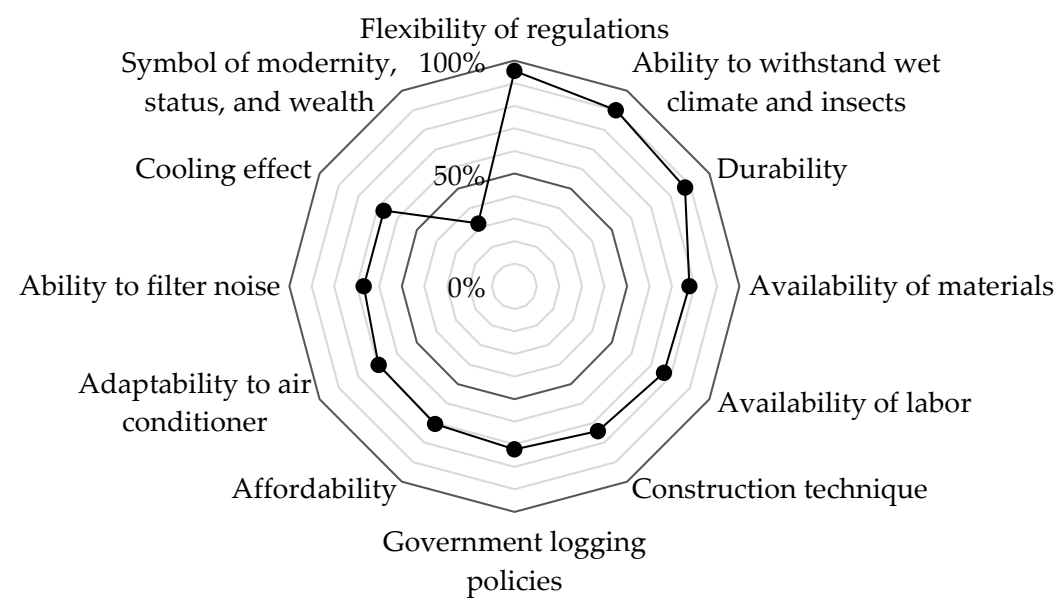

Figure 7. Percentage of local residents who highly rated each of the potential factors that influence their selection of building materials $(n=112)$.

Figure 8 shows the percentage of local residents who rated and compared traditional and modern materials based on each of the potential factors. Compared to traditional materials, modern materials have very good ratings on external factors and very strong inherent characteristics based on six factors: (1) ability to withstand wet climate and insects; (2) availability of materials; (3) availability of labor; (4) construction technique; (5) affordability; and (6) adaptability to air conditioner. This excludes the "government logging policies" factor that applies only to traditional materials. There is no significant difference in rating for "flexibility of regulations" because there is no restriction imposed on the use of building materials. This allows local residents to exercise their choice based on their priorities and interests.

Hence, modern materials are able to meet the requirements of five factors that highly influence locals' choice of materials. Modern materials also rated higher in five other influential factors that support the change. Therefore, locals changed to modern materials because they were more practical, have desirable qualities, and are not restricted by regulations. This finding is consistent with that of Vonvilay [28]. 


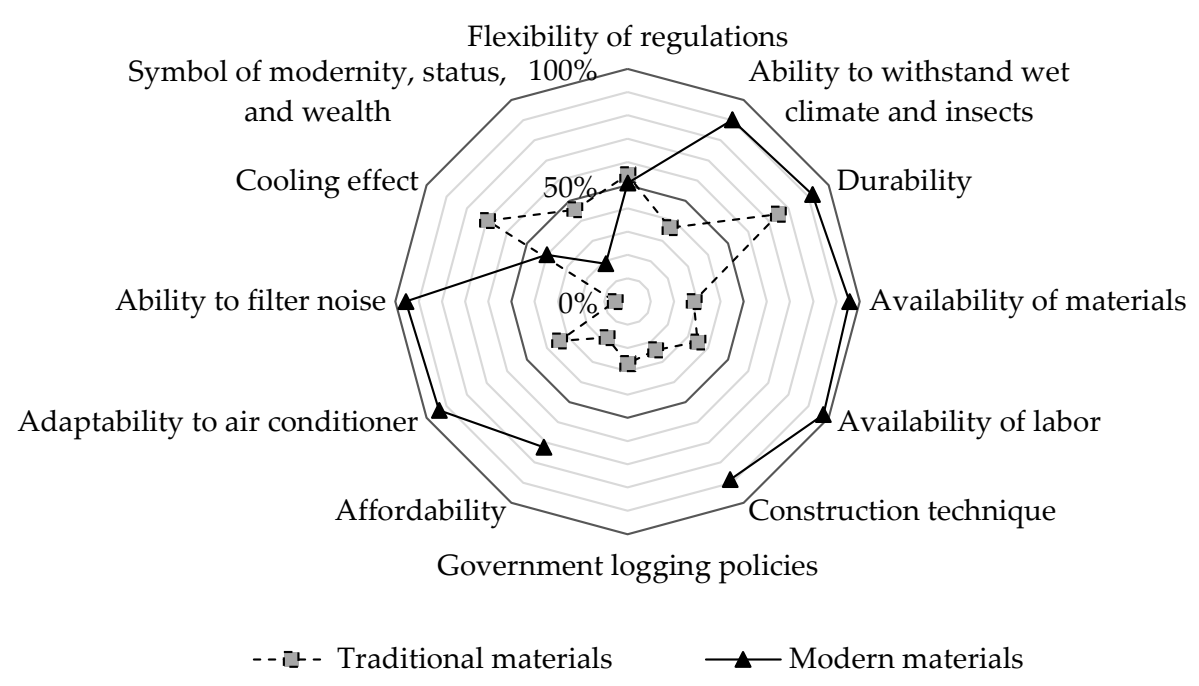

Figure 8. Percentage of local residents who highly rated and compared traditional and modern materials based on each of the potential factors $(n=112)$.

\subsection{Change in Roof Materials}

Buildings in Luang Prabang utilized traditional and modern roof materials. Traditional roof materials are comprised of clay tiles, cement tiles, timber, and bamboo. Modern roof materials include corrugated zinc sheets, fiber cement, and terrace. Figure 9a-c depict the spatial distribution of roof materials in 1999 and 2009 as well as the change in roof materials. The use of traditional roof materials has increased prominently and replaced modern roof materials in several areas along the riverbanks. Similar to that of architecture and traditional materials, use of traditional roof materials in the middle of the peninsula and on commercial roads is being maintained by inventory buildings. This implies that significant heritage buildings in these areas have maintained the original attributes of their architecture, building materials, and roof materials.

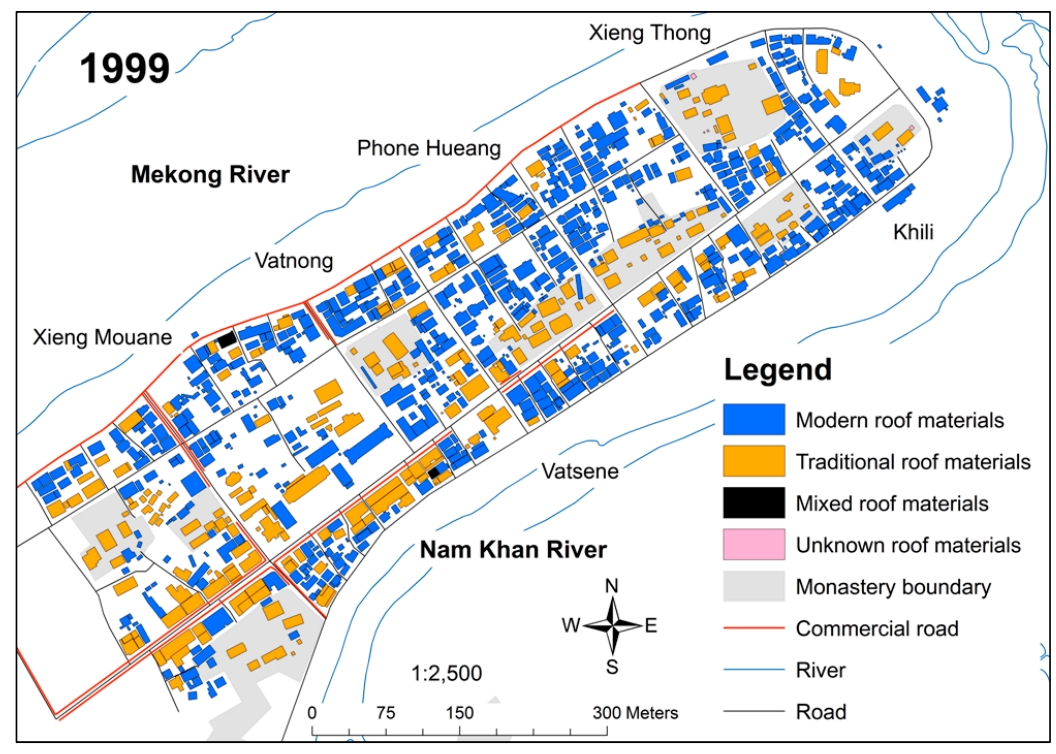

(a)

Figure 9. Cont. 


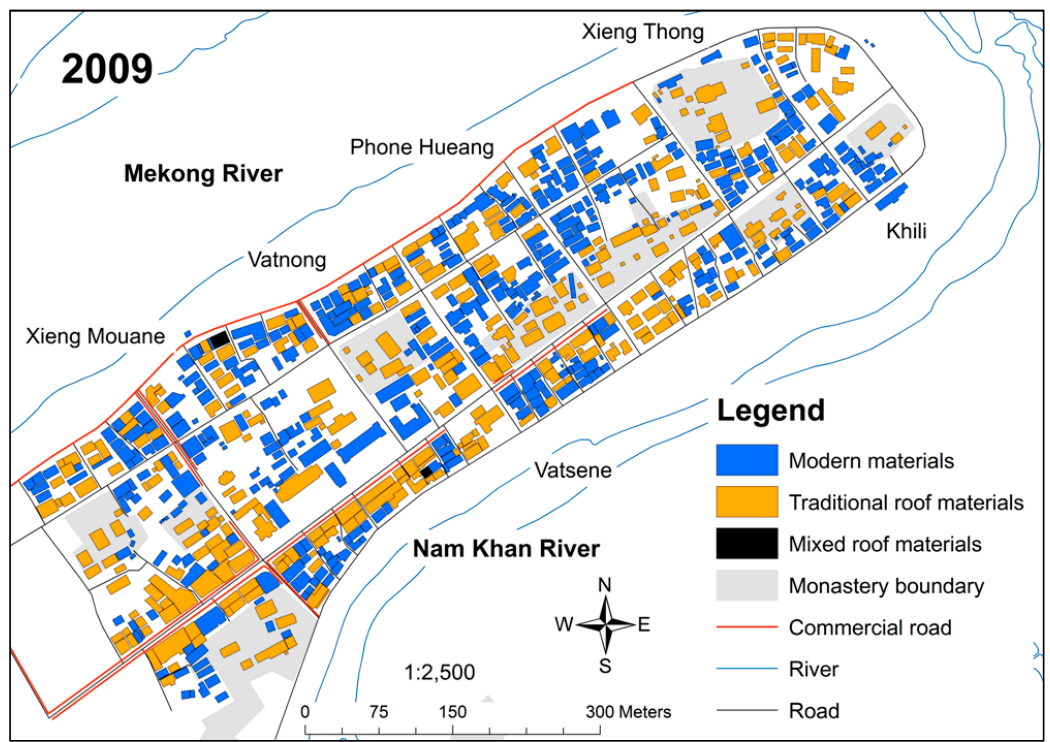

(b)

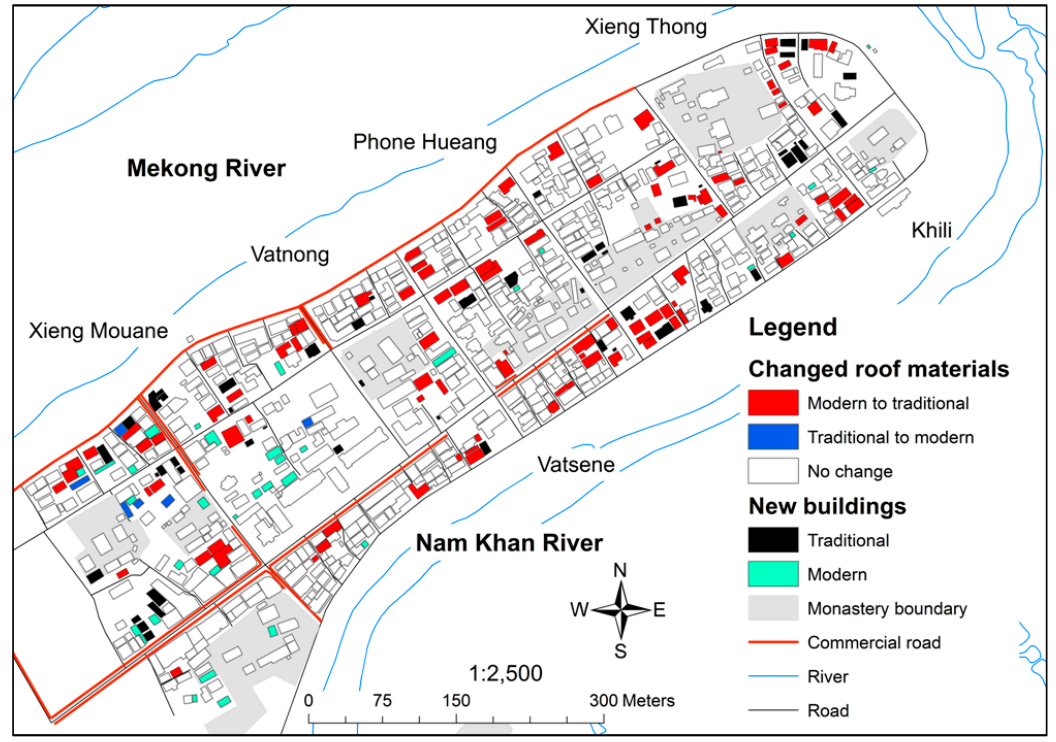

(c)

Figure 9. (a) Spatial distribution of building roof materials in 1999; (b) spatial distribution of building roof materials in 2009; and (c) change in roof materials between 1999 and 2009.

Table 9 summarizes the transition in roof materials. In ten years, the number of buildings with modern roof materials decreased from 473 to 401 . Buildings with traditional roof materials increased from 183 to 295 . A notable number of 92 buildings with modern roof materials converted to traditional roof materials. The majority of the demolished buildings had utilized modern roof materials. Furthermore, 49 new buildings utilized traditional roof materials compared to 33 buildings with modern roof materials. The change from traditional to modern roof materials is not as significant. There were 41 roofless structures in 1999, and this number increased to 47 in 2009. 
Table 9. Transition in roof materials between 1999 and 2009.

\begin{tabular}{|c|c|c|c|c|c|c|c|}
\hline & & \multicolumn{5}{|c|}{2009} & \multirow[b]{2}{*}{ Total } \\
\hline & & Modern & Traditional & None & Mixed Materials & Roofless Structures & \\
\hline \multirow{7}{*}{1999} & Modern & 346 & 92 & 35 & 0 & 0 & 473 \\
\hline & Traditional & 6 & 169 & 8 & 0 & 0 & 183 \\
\hline & None & 33 & 49 & 0 & 0 & 6 & 88 \\
\hline & Mixed materials 1 & 0 & 0 & 0 & 2 & 0 & 2 \\
\hline & Unknown $^{3}$ & 0 & 1 & 1 & 0 & 0 & 2 \\
\hline & Roofless structures ${ }^{2}$ & 0 & 0 & 0 & 0 & 41 & 41 \\
\hline & Total & 401 & 295 & 44 & 2 & 47 & 789 \\
\hline
\end{tabular}

${ }^{1}$ Special case of buildings that mixed the use of traditional and modern roof materials. They were built before the inscription of the site; ${ }^{2}$ Roofless structures are non-inhabitable structures such as stupas and small worship structures; ${ }^{3}$ Same description as Table 4.

The increase of traditional roof materials is perceived as having a positive impact on the landscape because the roof is the most visible part of a building. The sharp-angled roof is an important building feature that accentuates the unique architecture style of Luang Prabang. Construction of new buildings and restoration of existing buildings should have a roof slope between 35 and 60 degrees [14]. The sharp-angled roof design can only be achieved by using small-dimension roof tiles. Therefore, the use of roof materials is restricted to small-dimension tiles of $30 \mathrm{~cm}$ by $30 \mathrm{~cm}$. Title II, Section 2, Article 11-3 of the PSMV stipulated that the construction of new buildings and restoration of inventory buildings is obliged to use small-dimension traditional clay or cement tiles, and it prohibits the use of large-dimension fiber cement plates or corrugated zinc sheets [14].

Investigation with Local Residents

The increase of traditional roof materials could be driven by five factors. Four factors are summarized from the literature [22]: (1) durability; (2) availability of materials; (3) affordability; and (4) flexibility of regulations. The descriptions of the four factors are similar to those of the building materials in Table 7 of Section 5.3. The importance of the roof in architecture is an additional factor that was identified through a workshop with the DPL. Out of 92 residents who changed to traditional roof materials, 91 residents were interviewed, and one resident did not participate. The same approach as that of the interview administered for building materials was employed.

Locals have rated each of the potential factors that could influence their choice of roof materials, as shown in Figure 10. Local residents felt that three factors highly influenced their selection of roof materials: (1) the importance of the roof in architecture; (2) flexibility of regulations; and (3) durability. This illustrates that the aesthetic of the roof design, type of roof materials permitted, and the lifespan of the materials are very significant. The other two factors, i.e., affordability, and availability of materials, are also classified as influential.

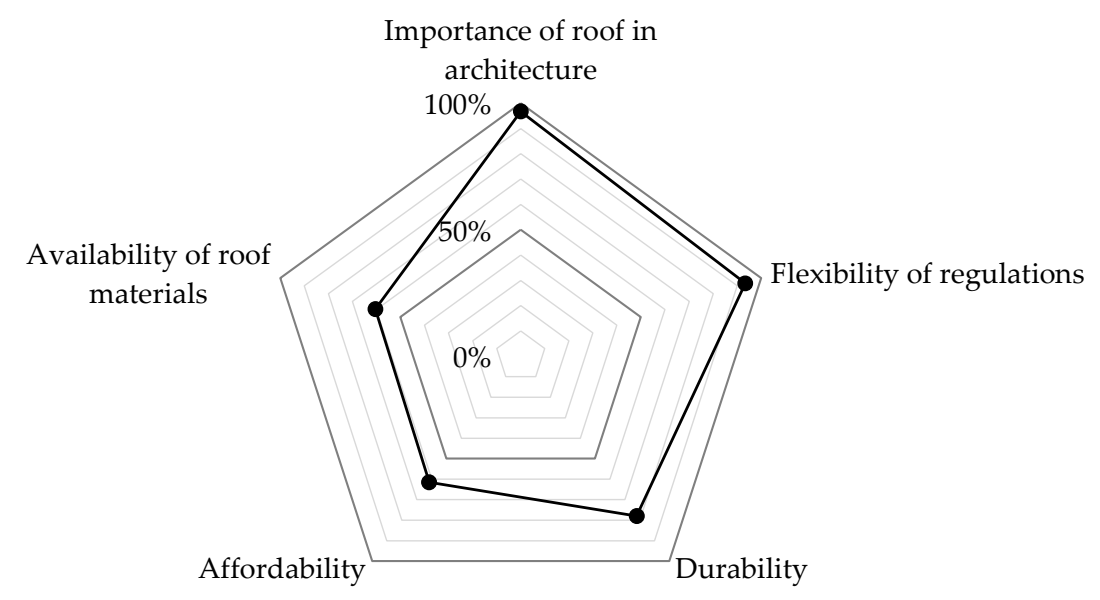

Figure 10. Percentage of local residents who highly rated each of the potential factors that influence their selection of roof materials $(n=91)$. 
In Figure 11, local residents rated and compared traditional and modern roof materials based on each of the potential factors. Traditional roof materials clearly stand out from modern roof materials regarding the factor of the importance of the roof in architecture. It was explained that the traditional roof materials are the only ones produced in the smaller dimension and easily laid out to construct the sharp-angled roof. Meanwhile, modern roof materials produced in larger dimensions are not flattering for the roof design. Traditional roof materials have good durability and availability of materials, but they do not have good affordability. On the other hand, modern roof materials are classified for their good durability, very good availability, and very good affordability. The ratings are not distinctly different for the "flexibility of regulations" factor because strict regulations dictate the use of traditional roof materials, and locals have no choice.

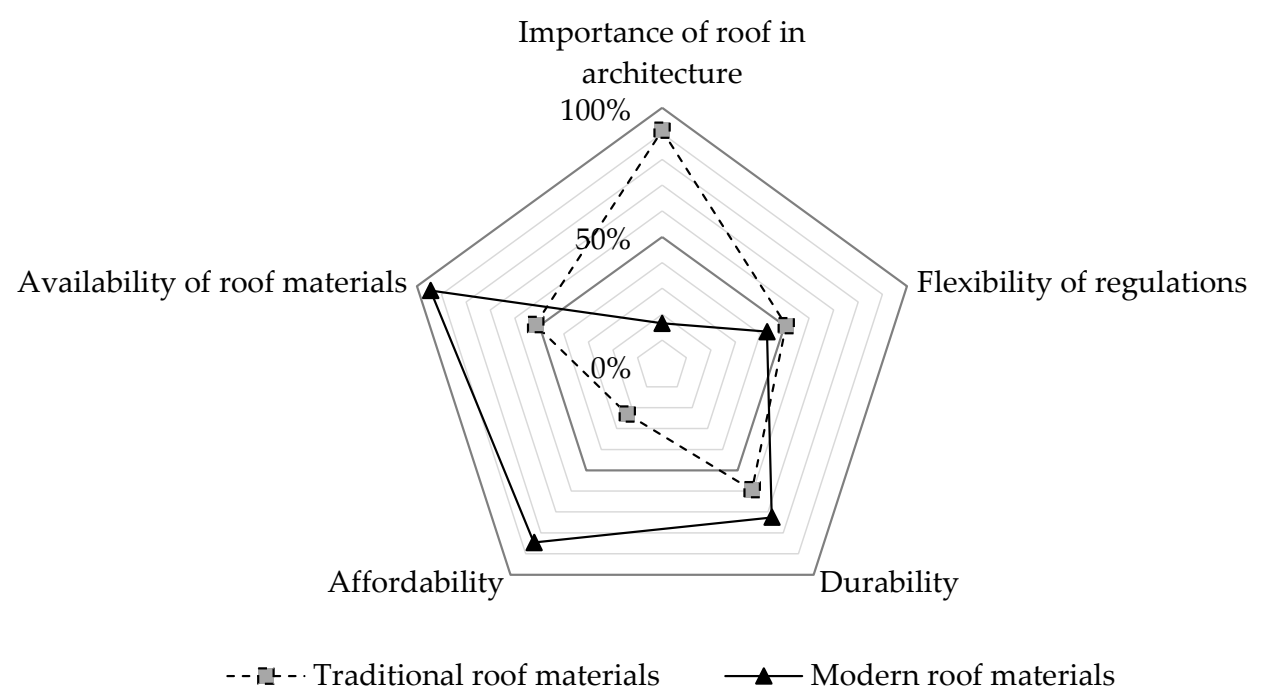

Figure 11. Percentage of local residents who highly rated and compared different roof materials based on each of the potential factors $(n=91)$.

In short, traditional roof materials are able to meet the requirements of three highly influential factors and one influential factor, excepting affordability. This overweighs the affordability factor. Hence, residents changed to traditional roof materials because of strict regulations, the importance of a sharp-angled roof design, good accessibility, and good durability. This is consistent with the UNESCO tourism impact report [22] that regulatory means to control the use of roof materials were able to revive the use of traditional roof materials.

\subsection{GIS Application for Historic Preservation}

Although this study is limited to six villages due to a lack of data and resources, demonstration of the pilot study serves as a baseline. Despite a relatively fundamental analysis having been carried out on the pilot site, the spatial analysis offered important insights into how the built environment of Luang Prabang has changed since its inscription. When the study was conducted, there was no reliable spatial data, and no prior research had been carried out. Thus, this study also envisaged GIS deployment in a more sustainable manner that tackled local constraints and catered to the local environment. The local government, the DPL, has expanded the digital base map to cover the entire World Heritage Site based on the pilot study. In response to the World Heritage Committee's recommendation that maps be prepared that show the full extent of the changes [11], the DPL was able to map the change in Luang Prabang and assess the state of conservation [39]. The DPL, based on the information derived from the expanded map, was able to identify countermeasures for potential problems. For example, conversion from residential to touristic use was occurring throughout the heritage site, and it raised the concern that locals are migrating to outside of the World Heritage Site [39]. As a countermeasure, 
French Development Agency (AFD) and the DPL collaborated to maintain the traditional functions of significant inventory buildings. An incentive fund was established to rehabilitate local houses, provided that the locals maintained their residential use. The information derived from GIS application is instrumental in managing change and thereby to assisting historic preservation of the site.

\section{Conclusions}

This study was able to deploy a localized GIS application with the aim of visualizing significant changes in the built environment of a pilot site in a core heritage area. Visualization using GIS and supported by the reasons behind the changes extracted from local residents was instrumental to clarifying and comprehending change in Luang Prabang. Four significant changes were identified between 1999 and 2009. First, an evident shift in building usage from residential to touristic use occurred along the riverbanks and main roads due to the demand for touristic accommodations. Second, Lao traditional architecture has replaced modern architecture due to strict regulations. In addition, residents have maintained existing Lao traditional architecture despite changing from residential to touristic use because respecting the regulations is the prerequisite to obtaining a business license. Third, modern building materials have replaced traditional building materials because modern materials have desirable qualities, are more practical to use, and locals are not restricted by regulations. Fourth, traditional roof materials have replaced modern roof materials because of strict regulations, the importance of the sharp-angled roof design, good accessibility, and durability. The main, prevalent reason behind the significant changes was the need to respect the PSMV. The PSMV has influenced the local residents' decisions in changing their buildings. The empirical evidence has shown that although touristic buildings have increased, important building characteristics have changed within the limits of preservation regulations.

Learning from the case of Luang Prabang, visualization of urban landscape characteristics and analysis of its changes are important for policy makers because it is difficult to perceive the entire landscape and its evolution without mapping its layout. The local authorities implemented preservation regulations to ensure that development occurs without compromising the outstanding universal value. The PSMV, the current regulatory tool enforced, is applicable and functioning to preserve the heritage site. Effective enforcement of the regulatory tool requires the commitment of local authorities and the cooperation of the local community. Therefore, the physical intervention has effectively revived the traditional characteristics and shaped the current built environment.

Acknowledgments: This research was funded by the Japan Society for the Promotion of Science (JSPS), Grant Number JP21404001, from 2009 until 2011. The authors greatly appreciate the close collaboration with the late Bounnhang Phongphichit, former Director of the DPL; Savuey Silavanh, current Director of the DPL; the Construction and Restoration Unit of the DPL; and the Information Communication and Technology (ICT) Unit of the DPL.

Author Contributions: Ceelia Leong designed the GIS application and analyzed the change in the pilot site of Luang Prabang. The entirety of this research was conducted under the supervision of Jun-ichi Takada and Shinobu Yamaguchi.

Conflicts of Interest: The authors declare no conflict of interest.

\section{Abbreviations}

The following abbreviations are used in this manuscript:

$\begin{array}{ll}\text { ADB } & \text { Asian Development Bank } \\ \text { ADUC } & \text { Chinon Development and City Planning Agency } \\ \text { DPL } & \text { Luang Prabang Department of World Heritage Site (La Department du Patrimoine Luang Prabang) } \\ \text { GIS } & \text { Geographic information systems } \\ \text { FOSS } & \text { Free and open source software } \\ \text { LNTA } & \text { Lao National Tourism Administration } \\ \text { ICOMOS } & \text { International Council on Monuments and Sites } \\ \text { ICT } & \text { Information and Communication Technology }\end{array}$




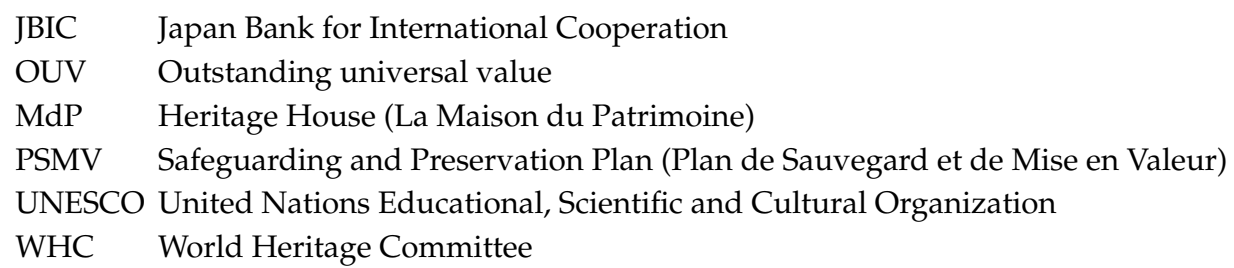

\section{References}

1. Hall, C.M.; Piggin, R. Tourism and World Heritage in OECD countries. Tour. Recreat. Res. 2001, 26, 103-105. [CrossRef]

2. Frey, B.S.; Steiner, L. World Heritage List: Does it make sense? Int. J. Cult. Policy 2011, 17, 555-573. [CrossRef]

3. Imon, S.S. Issues of Sustainable Tourism at Heritage Sites in Asia. In Asian Heritage Management: Contexts, Concerns, and Prospects; Silva, K.D., Chapagain, N.K., Eds.; Routledge: Oxford, UK, 2013; pp. 253-268.

4. Imon, S.S. Managing change in the historic city of Macao. Hist. Environ. 2008, 21, 16-21.

5. Ford, L.R. Continuity and change in Historic Cities: Bath, Chester, and Norwich. Geogr. Rev. 1978, 68, 253-273. [CrossRef]

6. Bandarin, F.; van Oers, R. The Historical Urban Landscape: Managing Heritage in an Urban Century; Wiley-Blackwell: Oxford, UK, 2012.

7. Stovel, H. Approaches to Managing Urban Transformation for Historic Cities. Review of Culture, 4th ed.; Cultural Institute of the Macau SAR Government: Macau, China, 2002; pp. 35-44.

8. Veldpaus, L.; Roders, A.R.P.; Colenbrander, B.J.F. Urban heritage: Putting the past into the future. Hist. Environ. Policy Pract. 2013, 4, 3-18. [CrossRef]

9. Box, P. GIS and Cultural Resource Management: A Manual for Heritage Managers; United Nations Educational, Scientific and Cultural Organization (UNESCO) Principal Regional Office for Asia and the Pacific: Bangkok, Thailand, 1999.

10. Khirfan, L. From documentation to policy-making: Management of built heritage in Old Aleppo and Old Acre. Tradit. Dwell. Settl. Rev. 2010, 21, 35-54.

11. Boccardi, G.; Logan, W. Reactive Monitoring Mission to the Town of Luang Prabang World Heritage Property Lao PDR, 22-28 November 2007; World Heritage Centre and the International Council on Monuments and Sites (ICOMOS): Paris, France, 2008.

12. Stovel, H. An Advisory Body View of the Development of monitoring for World Cultural Heritage. In World Heritage papers 10: Monitoring World Heritage; UNESCO, Ed.; UNESCO World Heritage Centre: Paris, France; International Centre for the Study of the Preservation and Restoration of Cultural Property (ICCROM): Rome, Italy, 2004; pp. 17-21.

13. Chinon Development and City Planning Agency (ADUC). Ten Years of Decentralised Cooperation between the Cities of Chinon and Luang Prabang Sponsored by UNESCO; UNESCO: Paris, France, 2005.

14. La Maison du Patrimoine (MdP). Heritage Preservation and Development Master Plan; La Maison du Patrimoine: Luang Prabang, Lao PDR, 2001.

15. ICOMOS. Advisory Body Evaluation, No. 735. 1995. Available online: http://whc.unesco.org/archive/ advisory_body_evaluation/479bis.pdf (accessed on 1 August 2016).

16. UNESCO. Convention Concerning the Protection of the World Cultural Natural Heritage. In Proceedings of the World Heritage Committee Nineteenth Session, Berlin, Germany, 4-9 December 1995.

17. Arteliers de la Peninsule. Luang Phabang, an Architectural Journey; Peninsula Group: Vientiane, Lao PDR, 2004.

18. MdP. Heritage Preservation and Development Master Plan Report; La Maison du Patrimoine: Luang Prabang, Lao PDR, 2001. (In French)

19. ADUC. Scheme for Coherent Territorial Development of Luang Prabang. Unpublished report, 2004. (In French)

20. Rural Development and Poverty Reduction Office. Statistics of Population of Luang Prabang District; Rural Development and Poverty Reduction Office: Luang Prabang, Lao PDR, 2011. (In Lao)

21. Department of Planning and Investment (DPI). Provincial Statistics on Tourism; Department of Planning and Investment: Luang Prabang, Lao DPR, 2015. (In Lao) 
22. UNESCO. Impact: The Effects of Tourism on Culture and the Environment in Asia and the Pacific: Tourism and Heritage Site Management in the World Heritage Town of Luang Prabang, Lao PDR; UNESCO and the School of Travel Industry Management University of Hawaii: Bangkok, Thailand, 2004.

23. Japan Bank International Corporation (JBIC). Pilot Study for Project Formation for the Luang Prabang Tourism Sector Development Project in Lao PDR: Interim Report. 2006. Available online: http://www. mekongtourism.org/wp-content/uploads/ITRMainText5_1.pdf (accessed on 30 November 2006).

24. Mabbit, R. Lao People's Democratic Republic. In Urbanization and Sustainability in Asia: Case Studies of Good Practices; Roberts, B., Kanaley, T., Eds.; Asian Development Bank (ADB): Mandaluyong, Philippines, 2006; pp. 189-221.

25. Sitthivan, S.; Komoto, J.; Abe, H. Actual situation of PSMV and problem in historic conservation area in Luang Prabang Province, Lao PDR. J. Arch. Plan. 2005, 591, 119-124. (In Japanese)

26. Dearborn, L.M.; Stallmeyer, J.C. Re-visiting Luang Prabang: Transformations under the influence of World Heritage designation. J. Tour. Cult. Chang. 2009, 7, 247-269. [CrossRef]

27. Dearborn, L.M.; Stallmeyer, J.C. Inconvenient Heritage: Erasure and Global Tourism in Luang Prabang; Left Coast Press: California, CA, USA, 2010.

28. Vonvilay, X.; Kang, Y.; Choi, J. The impact factors causing transformation of Lao traditional house: Case study of Luangprabang, Lao PDR. J. Korean Hous. Assoc. 2015, 26, 1-12. [CrossRef]

29. Staiff, R.; Bushell, R. Mobility and modernity in Luang Prabang, Laos: Re-thinking heritage and tourism. Int. J. Herit. Stud. 2013, 19, 98-113. [CrossRef]

30. Pierre, G. Safeguard of Luang Prabang's Urban Hydrosystem and Ponds. Unpublished report. 2008.

31. Irie, N. Study on Sustainable Development of Ponds and Wetlands in World Heritage Site using GIS: Case of Luang Prabang, Lao PDR. Master's Thesis, Tokyo Institute of Technology, Tokyo, Japan, March 2016.

32. Leong, C.; Yamaguchi, S.; Takada, J. Assessment on Local Condition in GIS Use in Sustainable Development of World Heritage Site: Case of Luang Prabang, Lao PDR. In Proceedings of the 44th International Society of City and Regional Planning (ISOCARP), Dalian, China, 19-23 September 2008.

33. Sitthirath, R.; Phompadith, S.; Savatvong, K.; Leong, C.; Takada, J.; Yamaguchi, S. Application of a Free and Open Source Database Management System for Heritage Management in Luang Prabang, Lao PDR. In Proceedings of the 2nd Joint International Conference on Information and Communication Technology, Electronic and Electrical Engineering (JICTEE), Vientiane, Lao PDR, 21-24 December 2010.

34. Leong, C.; Yamaguchi, S.; Takada, J.; Sitthirath, R.; Vannathy, P.; Phonesawat, X.; Sengnaly, P. Introducing GIS (Geographical Information System) to Monitor Development in the World Heritage Site of a Developing Country: Case of Luang Prabang, Lao PDR. In Proceedings of the 2nd Joint International Conference on Information and Communication Technology, Electronic and Electrical Engineering (JICTEE), Vientiane, Lao PDR, 21-24 December 2010.

35. Stewart, D.J. New tricks with old maps: Urban landscape change, GIS and historic preservation in the less developed world. Prof. Geogr. 2001, 53, 361-373. [CrossRef]

36. Mitchell, A. The ESRI Guide to GIS Analysis, Volume 1: Geographic Patterns and Relationships; ESRI Press: California, CA, USA, 1999; pp. 149-173.

37. Somphanvilay, K.; Deputy Director, Department of Tourism, Luang Prabang, Lao PDR. Personal communication, 2011.

38. Ministry of Agriculture and Forestry of Lao PDR. Forestry Strategy to the Year 2020 of Lao PDR; Ministry of Agriculture and Forestry of Lao PDR: Vientiane, Lao PDR, 2005.

39. Savourey, C.; Sivigny, A. 20 Years for Heritage and Development, Chinon/Luang Prabang: Decentralised Cooperation under the Aegis of UNESCO, \#2 (2005-2015); UNESCO: Paris, France, 2015.

(C) 2016 by the authors; licensee MDPI, Basel, Switzerland. This article is an open access article distributed under the terms and conditions of the Creative Commons Attribution (CC-BY) license (http://creativecommons.org/licenses/by/4.0/). 